AperTO - Archivio Istituzionale Open Access dell'Università di Torino

\title{
Stripping paradigmatic relations out of the syntax
}

\section{This is a pre print version of the following article:}

Original Citation:

Availability:

This version is available http://hdl.handle.net/2318/1680797

since 2019-04-12T09:40:22Z

Published version:

DOI:10.1007/s11525-018-9326-2

Terms of use:

Open Access

Anyone can freely access the full text of works made available as "Open Access". Works made available under a Creative Commons license can be used according to the terms and conditions of said license. Use of all other works requires consent of the right holder (author or publisher) if not exempted from copyright protection by the applicable law. 


\section{Author Query Form}

\section{Springer}

\begin{tabular}{|ll|l|}
\hline Journal: & JOMO & $\begin{array}{l}\text { Please send your responses together with your list of corrections via web } \\
\text { (preferred), or send the completed form and your marked proof to: } \\
\text { Mokslininku 2a, LT-08412 Vilnius, Lithuania } \\
\text { fax: }+37052729501 \\
\text { e-mail: vtexspr-corrections@vtex.lt }\end{array}$ \\
\hline
\end{tabular}

Dear Author,

During the preparation of your manuscript for typesetting, some questions have arisen. These are listed below.

\section{Queries and/or remarks}

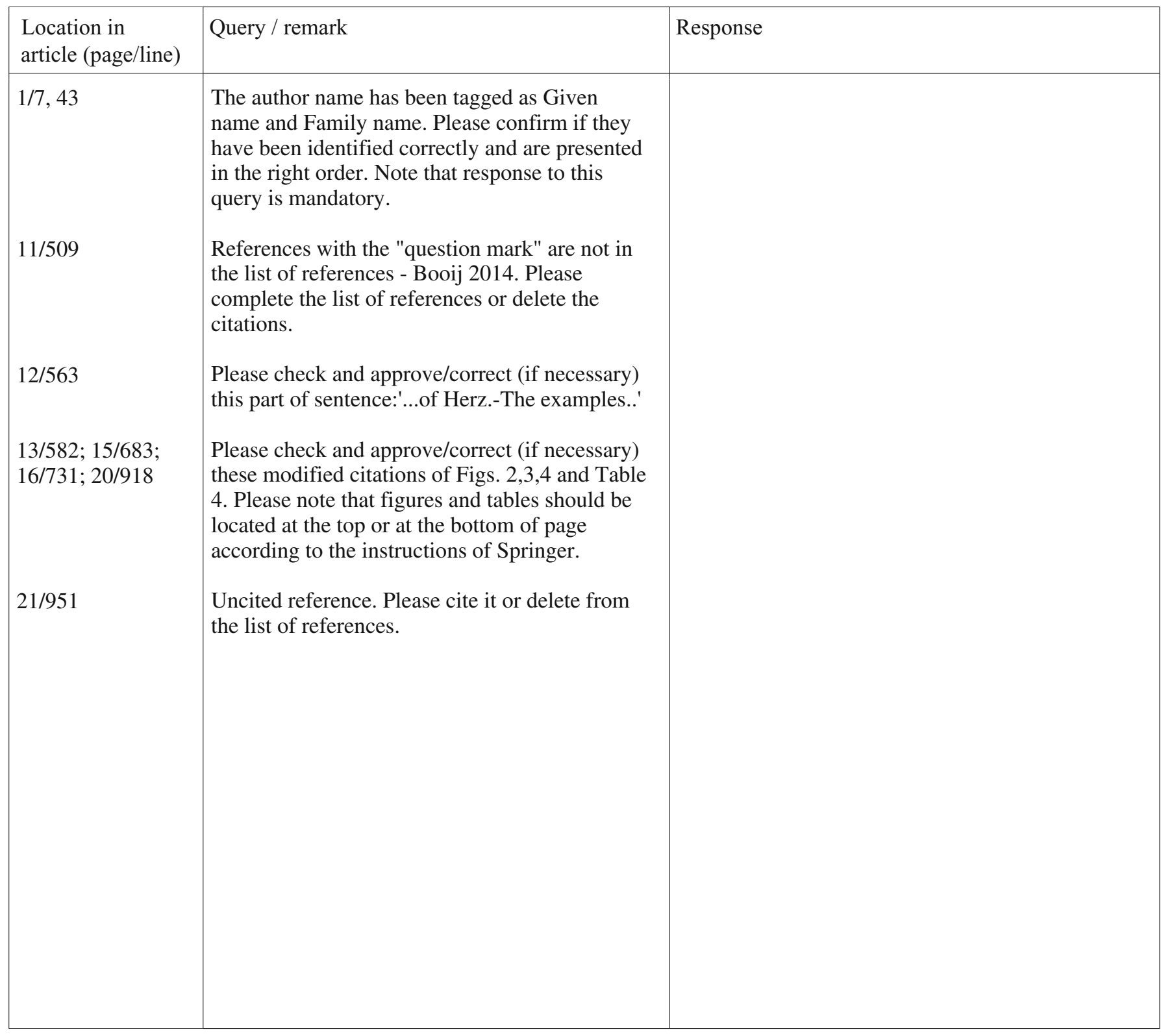




\section{Metadata of the article that will be visualized in Online First}

\begin{tabular}{|c|c|c|}
\hline Journal Name & \multicolumn{2}{|l|}{ Morphology } \\
\hline Article Title & \multicolumn{2}{|c|}{ Stripping paradigmatic relations out of the syntax } \\
\hline Copyright holder & \multicolumn{2}{|c|}{$\begin{array}{l}\text { Springer Science+Business Media B.V., part of Springer Nature } \\
\text { This will be the copyright line in the final PDF. }\end{array}$} \\
\hline \multirow[t]{5}{*}{ Corresponding Author } & $\begin{array}{l}\text { Family name } \\
\text { Particle }\end{array}$ & Gaeta \\
\hline & $\begin{array}{l}\text { Given Name } \\
\text { Suffix } \\
\text { Division }\end{array}$ & Livio \\
\hline & Organization & University of Turin \\
\hline & Address & Turin, Italy \\
\hline & E-mail & livio.gaeta@unito.it \\
\hline \multirow[t]{5}{*}{ Author } & $\begin{array}{l}\text { Family name } \\
\text { Particle }\end{array}$ & Angster \\
\hline & $\begin{array}{l}\text { Given Name } \\
\text { Suffix } \\
\text { Division }\end{array}$ & Marco \\
\hline & Organization & University of Zadar \\
\hline & Address & Zadar, Croatia \\
\hline & E-mail & \\
\hline \multirow[t]{2}{*}{ Schedule } & $\begin{array}{l}\text { Received } \\
\text { Revised }\end{array}$ & \\
\hline & Accepted & 16 May 2018 \\
\hline Abstract & \multicolumn{2}{|c|}{$\begin{array}{l}\text { This contribution aims at showing how paradigms and associative relations can be } \\
\text { integrated into word-formation, with special attention paid to compounding. In this } \\
\text { regard, we will take into account a phenomenon at the border between derivation and } \\
\text { compounding, namely formations like süßherzig 'sweet-hearted', in which -ig is } \\
\text { an adjective-forming suffix and AN a possible compound. To do so, we will explore } \\
\text { data available from a large web corpus, on whose basis we will show how } \\
\text { syntagmatic and paradigmatic relations developed in syntax find their way into word } \\
\text { formation. We will show that the most productive compounding schemas as they are } \\
\text { currently assumed in Construction Morphology give rise to processes of semi- } \\
\text { affixation which are a first step toward derivation proper. }\end{array}$} \\
\hline
\end{tabular}

Keywords

Footnotes

Parts of this paper were presented at the workshop on "Paradigms in Word

Formation" held during the 49th International Annual Meeting of the Societas Linguistica Europaea at the University of Naples "Federico II" (31.8.-3.9.2016), as well as in a lecture given at the University of Erlangen (16.1.2018). We thank all people attending the workshop, and especially Fiammetta Namer and Nabil Hathout, as well as two anonymous reviewers for helpful comments and remarks. Needless to say, all remaining mistakes are ours. 


\title{
Stripping paradigmatic relations out of the syntax
}

\author{
Livio Gaeta $^{1}$ (D) Marco Angster ${ }^{2}$ \\ Received: 26 July 2017 / Accepted: 16 May 2018 \\ (c) Springer Science+Business Media B.V., part of Springer Nature
}

\begin{abstract}
This contribution aims at showing how paradigms and associative relations can be integrated into word-formation, with special attention paid to compounding. In this regard, we will take into account a phenomenon at the border between derivation and compounding, namely formations like süßherzig 'sweet-hearted', in which -ig is an adjective-forming suffix and AN a possible compound. To do so, we will explore data available from a large web corpus, on whose basis we will show how syntagmatic and paradigmatic relations developed in syntax find their way into word formation. We will show that the most productive compounding schemas as they are currently assumed in Construction Morphology give rise to processes of semi-affixation which are a first step toward derivation proper.
\end{abstract}

\section{Introduction}

Construction Morphology crucially centers on the idea that word-formation patterns emerge syntagmatically by means of a number of formal operations such as conflation, word-group derivation, etc. (cf. Booij 2010; Gaeta 2006). This is particularly the case in a language like German, in which compounds are extremely productive (see Gaeta and Schlücker 2012). On the other hand, at least since Ferdinand de Saussure associative relations, which basically underlie paradigmatic modeling, have been

Parts of this paper were presented at the workshop on "Paradigms in Word Formation" held during the 49th International Annual Meeting of the Societas Linguistica Europaea at the University of Naples "Federico II" (31.8.-3.9.2016), as well as in a lecture given at the University of Erlangen (16.1.2018). We thank all people attending the workshop, and especially Fiammetta Namer and Nabil Hathout, as well as two anonymous reviewers for helpful comments and remarks. Needless to say, all remaining mistakes are ours.

L. Gaeta

livio.gaeta@unito.it

1 University of Turin, Turin, Italy

2 University of Zadar, Zadar, Croatia 
claimed to play a relevant role in word-formation. Clearly, one has to distinguish carefully between a concept of paradigm "narrow sense" from a paradigmatic dimension "broad sense": while the former plays a major role in inflectional morphology, which has been defined by its nature prototypically paradigmatic, the latter often shows up in word-formation research whereby it is not clear whether and to what extent the two senses correspond to each other and even overlap.

In this paper, we will try to defend the view that far from being different the concepts of paradigm "narrow sense" and of paradigm "broad sense" highlight different facets of the same procedural mechanism activated by the speakers when they elaborate on vertical and horizontal associations established among words on the basis of pattern similarity. In particular, we will devote our attention to complex formations in German resulting from the combination of recurrent patterns of AN compounds and of AN phrases on the one hand, and on the other on derivatives formed by means of a highly productive suffix like -ig: this gives rise to bracketing paradoxes requiring (para-)synthetic derivation because for instance a formation like hochfiebrig 'having high fever' cannot be formed on 'fiebrig nor on ${ }^{\circ} H o c h f i e b e r$ while its syntactic correspondent hohes Fieber 'high fever' is widely attested.

The paper is structured as follows: in Sect. 2 some theoretical background is given discussing in particular the role of paradigms and associative relations within the Constructicon; in Sect. 3 we will briefly discuss with the help of a concrete example the conceptual and empirical differences between the usage of paradigm in inflection and in word-formation, carefully distinguishing between the latter's subparts, namely derivation and compounding; in Sect. 4 we will devote our attention to the role of paradigms in compounding as a specific case of word-formation, while in Sect. 5 the particular case of AN-ig formations (called Zusammenbildungen in the German literature, which in a way correspond to English deverbal synthetic compounds like sweet-hearted) will be introduced which give rise to different paradigmatic processes and in Sect. 6 the systematic subtypes of AN-ig formations will be discussed in the light of their corresponding AN phrases; in Sect. 7 single instantiations of paradigm families relating to the general $\mathrm{AN}$-ig pattern will be discussed in detail; the final Sect. 8 draws the conclusion.

\section{Paradigms, associative relations and the constructicon}

Traditionally, the paradigmatic dimension is deemed to characterize inflectional morphology in neat contrast with derivational morphology. Conversely, the latter is held to be more connected with the syntagmatic dimension as it provides words to be inserted into syntactic structures. In older models (see for instance Scalise 1984:6-8 for a discussion), this operation used to be called lexical insertion and is clearly distinct from inflection insofar as it takes into consideration lexemes while inflectional morphology usually provides word forms appropriately selected for a given syntactic node among a closed set of possibilities. While lexical insertion as such does not apparently require any reference to a paradigm because any lexeme can in principle be inserted into a syntactic structure, inflectional morphology comes into play after lexical insertion, once the lexeme has been selected because the appropriate word 
form needs to match the fixed number of morphosyntactic properties required by the syntactic environment. In other words, it is the property of closure which keeps inflectional morphology distinct from derivational morphology (cf. Aronoff 1976:2). Accordingly, a word (or inflectional) paradigm is a finite set of possible word forms generated by the (implementation of the) inflectional categories occurring in a given language (cf. Gaeta 2007 for a discussion of the issue of productivity in inflection). This corresponds to the notion of paradigm "narrow sense" hinted at above.

Very much in tune with this view, a realizational interpretation of the paradigm has been recently made current, as in Carstairs' (1987:48-49) following definition (cf. also Stump 2005 for a discussion):

"A paradigm for a part of speech $\mathrm{N}$ in a language $\mathrm{L}$ is a pattern $\mathrm{P}$ of inflexional realizations for all combinations of non-lexically-determined morphosyntactic properties associated with $\mathrm{N}$ such that some member of $\mathrm{N}$ exemplifies $\mathrm{P}$ (i.e. displays all and only the realizations in P)".

This definition strictly connects the concept of paradigm with the number of morphosyntactic properties associated with a certain lexeme, independently of any formal relation of morphological nature. In this way, suppletive realizations are easily captured by the definition, while only combinations of lexically-determined morphosyntactic properties are excluded from the count.

One problem with this view is that it is only feasible if a clear distinction can be drawn between lexically- and non-lexically-determined morphosyntactic properties. As is well known, this is not always easy to do. In fact, it is not clear how far morphological categories like verbal adjectives (participles) or verbal nouns (infinitives) are expressed in terms of non-lexically-determined morphosyntactic properties while others (e.g. adverbs) are not. To make one concrete example, everybody agrees with the assumption of a specific slot for drinking within the paradigm of the verb to drink, but it is not clear why the slot for the verbal adjective drinkable is normally rejected. In a similar way, in the paradigm of an adjective, e.g. fast, one normally counts the comparative and superlative forms faster and fastest, but only few also include the adverb fastly.

On the other hand, alleged non-lexically-determined morphosyntactic properties normally modeling inflectional paradigms are often subject to limits intrinsic to single lexemes which makes them strictly lexically-determined: for instance, defective paradigms (e.g., Italian prudere 'to itch'/past participle: ??pruso, ??prudito) are much more frequent than one normally reads in language descriptions (cf. Baerman and Corbett 2010 for a discussion). Moreover, other limits on the size of the paradigms come from general constraints on their extension: e.g., English intransitive verbs normally do not form the passive, stative verbs do not form the imperative or the progressive form, etc. Clearly, such differences are related to the specific properties of the single lexeme, i.e. they are lexically-determined. This renders the boundaries of a paradigm difficult to draw. As a matter of fact, one cannot tell whether such restrictions refer to the actualization of a pattern giving rise to possible, but unattested word forms like ${ }^{\circ}$ was slept,${ }^{\circ}$ am knowing, ${ }^{\circ}$ know!, etc., or whether these word forms are to be considered ungrammatical. In a way, this reminds us of the problem raised by derivatives like decaffeinate which implies the intermediate step ${ }^{\circ}$ caffeinate (cf. Gaeta 2015 for a discussion). 
Finally, language change often has the effect of blurring the boundaries insofar as single forms are taken to enter or to leave the paradigm. For instance, the actual participle drinking used to be a verbal noun normally not included into the paradigm of an Old English verb while it's not clear what to do with old participles like shaven which only behaves as an adjective nowadays: John is shaven (*by his mother). In short, even if we were to agree with Carstairs' definition given above, drawing a clear line between what has to be included into an inflectional paradigm and what has to be left out remains a difficult and in certain cases meaningless task.

On the other hand, since the early days of modern linguistics there has always been a wide consensus on the central role played by paradigmatic or associative relations in the language as already envisaged by Ferdinand de Saussure. This intuition can be placed at the core of how we figure out that a morphological relation should be, namely a form/meaning relation of any kind, and corresponds to the concept of paradigm "broad sense" hinted at in Sect. 1 above. The intuition of basic associative relations can be expanded into a more general procedure for cross-referencing, if the relation proves to be minimally systematic. This idea lies behind Bauer's general assumption of a paradigm not only for inflectional morphology but also in wordformation proper:

"[C]ross-referencing within the paradigm is the only way to find a regular way to generate the appropriate forms, and that means that the derivational paradigm must be at the heart of a generative grammar, even if there are times when derivational paradigms do not appear to be totally regular" (Bauer 1997:254).

Note that Bauer himself provides an example of how minimally systematic an associative relation can be: the English lexeme bishop (besides the plural form bishops, of course) only cross-refers to the overt derivative bishopric-besides the conversion to bishop - and viceversa: the only reason for assuming -ric is its occurrence in bishopric (cf. Bauer 2001:47). In fact, a certain degree of systematicity is usually required to provide associative relations with a certain paradigmatic strength. The latter refers to a double dimension: on the one hand, an associative relation is made more and more robust by increasing the number of word pairs in which it occurs. Accordingly, the relation between bishop and bishopric is unique throughout the English lexicon and accordingly its paradigmatic strength is very weak within the realm of the procedures forming IPLACEl from an input basis. In a different way, one normally says that the productivity of the suffix -ric is limited to the base bishop. On the other hand, the paradigmatic strength is increased by the number of the derivatives formed with a certain base, namely its family size. Also from this perspective the family size of bishop is limited to the only derivative bishopric, again besides the conversion to bishop.

To give an immediate perception of the relevance of concepts like paradigmatic strength and family size we can adopt a constructional view of morphology as it has been suggested in recent research (cf. Booij 2010; Jackendoff and Audring 2016; Gaeta and Zeldes 2017). In this view, morphological schemas — on the one hand — and simple as well as complex lexemes - on the other-occur side by side in a network (the Constructicon, cf. Goldberg 2013) differing in generality and specification:

Two things are relevant in this figure: first, the similar status of fully specified lexemes like bishop, bishopric, king, kingdom, etc. and of underspecified schemas 


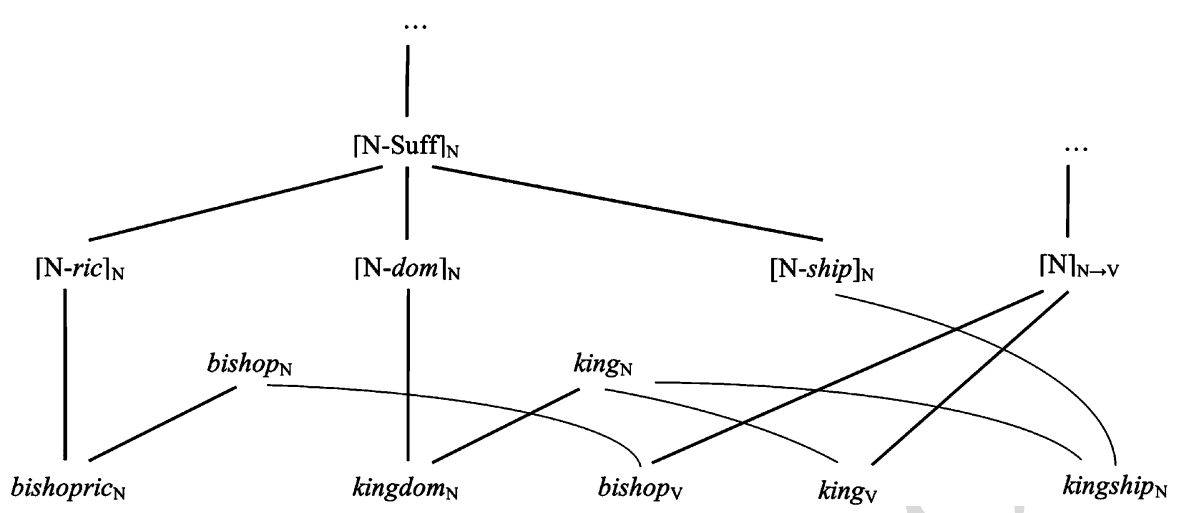

Fig. 1 Relational networking within the Constructicon

such as [N-ric], [N-dom], [N-ship] and the like. By doing so, the network is able to encode both the representational dimension typically associated with the lexicon and the generative capacity typically associated with the word-formation component: in this regard, both dimensions are simultaneously contained in the schemas.

The second thing is the concept of inheritance hierarchy and of schema unification which allows the speakers to go up and down the network insofar as the properties of the single schemas are inherited top-down while schemas are unified bottom-up and further generalized over more and more subschemas. In this way, inheritance hierarchy and schema unification give expression to the vertical as well as to the horizontal dimension implied both by paradigmatic modeling and by Saussurean associative relations. In fact, the network clusters around more general schemas, which are then implemented in more specific subschemas, which in their turn can be horizontally connected with other low-level schemas pushing the link further to other more general schemas, and so on.

On this background, family size can be intended along two different axes (cf. Štekauer 2014): a horizontal axis which collocates the involved pattern together with others sharing the same derivational meaning or more in general cognitive category, but differing for instance in productivity, as shown by [N-ric] and [N-dom] in Fig. 1 above for place names, and a vertical axis in which the involved pattern is listed close to others based on the same word, as in king $\rightarrow$ kingdom, kingship, etc. Accordingly, in (1a) the derivational paradigm of the cognitive category |AGENT| is reported including the example of a compounding strategy, milk $\rightarrow$ milkman, which shows how in principle the concept of paradigm can be applied in word-formation even beyond the limits of derivation proper:

(1) a. teach $\rightarrow$ teacher, journal $\rightarrow$ journalist, library $\rightarrow$ librarian, escape $\rightarrow$ escapee, milk $\rightarrow$ milkman

b. písat' 'to write' $\rightarrow$ za-písat' 'to record by writing' $\rightarrow$ zapis-ovat' 'to keep recording by writing' $\rightarrow$ zapisova-teI 'registrar/recorder' $\rightarrow z a$ -

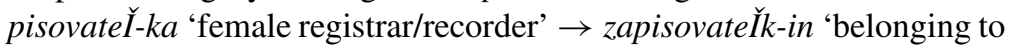
female registrar, recorder' 
c. $\quad$ škola 'school' $\rightarrow$ škol-ák 'schoolboy'

$\rightarrow$ škol-ník 'school janitor'

$\rightarrow$ škôl-ka 'kindergarten'

$\rightarrow$ škol-stvo 'education system'

$\rightarrow$ škol-ička 'small school'

Such a derivational paradigm profiles a family of derivatives sharing the same basic meaning. On the other hand, the family of a word can be quite rich as in Slovak (cf. Furdík 2004:73-74) insofar as it may comprehend the successive applications of different processes to an initial base-word (1b), or of the different processes applicable to a single base-word (1c). Keeping in mind on the one hand the Constructicon and its architectural properties and on the other the double dimension connected with paradigmatic strength and family size as they are underpinned by associative relations, we will explore in this paper how useful the concept of derivational paradigm can be in order to account for a number of associative relations which pop out from recurrent patterns resulting from the combination of compounding and suffixation in German. This makes this paper one of the first attempts to apply the concepts and the modeling of paradigmatic morphology beyond the realm of derivational processes. To do this, we will rely on data available from the corpus DeWaC which is a huge corpus of the German language featuring about 2 billion tokens constructed in the realm of Web-as-a-Corpus projects (cf. Baroni et al. 2009).

\section{Paradigms between inflection and word-formation}

With the help of a concrete, and perhaps somewhat trivial, example let us start with discussing the main differences between inflection and derivation and, within wordformation, between derivation and compounding, as far as the concept of paradigm is concerned.

If we consider a German adjective like hoch 'high', this is characterized by a rich word paradigm, corresponding to all slots generated by the different values of gender (3: masculine, feminine and neuter), number (2: singular and plural; in the plural, the gender distinctions are neutralized), case (4: nominative, accusative, dative and genitive) and definiteness (2: the so-called strong and weak forms). ${ }^{1}$ German also has synthetic forms for comparative and superlative, and these additional dimensions triplicate the number of the resulting slots.

As far as base allomorphy is concerned, German hoch has four different allomorphs: hoch, used only in the predicative use (Der Turm ist hoch 'The tower is high'), hoh- used in the positive forms, höh(er)- which builds the comparative and $h \ddot{c} c h(s t)$ - used for building the superlative.

\footnotetext{
${ }_{1}^{1}$ As is well known, German adjectives display different forms if they are preceded by the determinative article (weak forms) or not (strong forms). However, the whole paradigm — and especially among the weak forms - is filled with homonymous forms, i.e. widespread syncretism: the forms hohe and hohen alone fill all the slots in the weak paradigm, e.g. no case distinction is conveyed by the adjective in plural weak forms and no gender distinction is conveyed by the adjective in nominative, dative and genitive singular weak forms.
} 
The same word paradigm that we have described for hoch is applicable to basically all German adjectives (2a), possibly with different patterns of allomorphy involved (2b):

\section{a. klein 'small': klein-ler-/est- \\ b. kalt 'cold': kalt- kälter-lest-}

Further, each new German adjective is immediately provided with a regular paradigm of this type. In fact, the presence of a paradigm of forms is often regarded as a defining feature of inflectional phenomena as opposed to derivational ones (cf. Štekauer 2015 for a discussion).

However, on the one hand inflection is not exception-free as a number of adjectives do not inflect for a number of reasons, e.g. prima 'fine, cute' sand 'sand', etc. (cf. Gaeta 2010, 2014). On the other hand, derivation is not chaotic and, to some extent, the same relationship between whatever adjective and its inflectional forms can hold between an adjective and its derivatives.

Taking once again German hoch into account, it can access several derivational processes as any other German adjective. One can derive for example nouns, adverbs and verbs:

$$
\begin{aligned}
& \text { a. hoch } \rightarrow \text { hoh- }+ \text {-heit } \rightarrow \text { Hoheit 'Highness' } \\
& \text { b. hoch } \rightarrow \text { höh- }+-e \rightarrow \text { Höhe 'height' } \\
& \text { c. hoch } \rightarrow \text { höch }(s t)-+- \text { ens } \rightarrow \text { höchstens 'at most' } \\
& \text { d. hoch } \rightarrow \text { höh- }+-\emptyset_{\mathrm{V}-} \rightarrow \text { höhen '(in painting) to highlight with opaque } \\
& \text { white' }
\end{aligned}
$$

Each of these processes is applicable to many other German adjectives.

$$
\begin{aligned}
& \text { a. niedrig } \rightarrow \text { niedrig- }+ \text {-heit } \rightarrow \text { Niedrigkeit 'the fact of being low' } \\
& \text { b. kalt } \rightarrow \text { kält- }+-e \rightarrow \text { Kälte 'cold (weather, environment)' } \\
& \text { c. erst } \rightarrow \text { erst- }+- \text { ens } \rightarrow \text { erstens 'firstly' } \\
& \text { d. falsch } \rightarrow \text { fälsch- }+-\emptyset_{\mathrm{V}} \rightarrow \text { fälschen 'to falsify, to fake' }
\end{aligned}
$$

However, differently from inflection, we cannot take it for granted a priori that for each German adjective every possible derivational process is concretely actualized, and this is also connected to the fact that derivational processes usually display different grades of productivity (or rentability, as defined in Bauer 2001, cf. Gaeta and Ricca 2015 for an overview).

Table 1 shows the five adjectives and the four processes exemplified above (in particular, the suffixes - heit and - $e$ give rise to abstract nouns, the suffix -ens forms adverbs based on the superlative or elative form, and the conversion forms verbs) and gives an impressionistic idea of how many gaps actually exist in a hypothetical derivational paradigm. This state of affairs is a good representation of Bauer's description of how a derivational paradigm can be conceived of:

\footnotetext{
${ }^{2}$ Here, the traditional zero-suffix $-\emptyset_{V}$ - for forming verbs is assumed. See Gaeta (2013) for a discussion of the alternative conversion hypothesis. The pattern PREFIX-ADJ- $\emptyset_{\mathrm{V}}$-which is called Präfixkonversion 'prefix conversion' in German (cf. Fleischer and Barz 1992:308)-is more productive in the formation of de-adjectival verbs. See for example hoch $\rightarrow$ er- + höh- $+-\emptyset_{\mathrm{V}} \rightarrow$ erhöhen 'to raise, increase', hoch $\rightarrow$ auf- + höh- $+\emptyset_{\mathrm{V}} \rightarrow$ aufhöhen 'to heighten'.
} 
«JOMO 11525 layout: Small Extended v.2.1 file: jomo9326.tex () class: spr-small-v1.4 v.2017/12/27 Prn:2018/05/24; 10:47 p. 8/22» doctopic: OriginalPaper numbering style: ContentOnly reference style: apa»

L. Gaeta, M. Angster

Table 1 The derivational paradigm of hoch 'high, 3

\begin{tabular}{|l|l|l|l|l|}
\hline & - heit $\mathrm{N}$ & $-e_{\mathrm{N}}$ & -ens $\mathrm{Adv}$ & $\emptyset_{\mathrm{V}}$ \\
\hline erst & ${ }^{\circ}$ Erstheit & ${ }^{\circ}$ Erste & erstens & ${ }^{\circ}$ ersten \\
\hline falsch & Falschheit & ${ }^{\circ}$ Fälsche & ${ }^{\circ}$ fälschestens & fälschen \\
\hline hoch & Hoheit & Höhe & Höchstens & höhen \\
\hline kalt & ${ }^{\circ}$ Kaltheit & Kälte & ${ }^{\circ}$ kältestens & kälten \\
\hline niedrig & Niedrigkeit & ${ }^{\circ}$ Niedrige & ${ }^{\circ}$ niedrigstens & ${ }^{\circ}$ niedrigen \\
\hline
\end{tabular}

"[T]here are constellations of positions in matrices which, while they may be filled in ways which are so irregular as to put them outside what is traditionally viewed as inflection, can nonetheless be considered slots which must be available for any word of the appropriate word-class. These available slots are the paradigm.” Bauer (1997:253)

Further elaborating on this, Štekauer (2014) concludes that:

"[p]otentiality is a crucial term for the concept of derivational paradigm. It guarantees a high level of predictability and regularity [...] in the sense that the existing gaps in the system can be filled anytime with actual words."

He further points out that "one of the essential features of the derivational paradigm is the availability of slots (filled with potential words) that are more important for the paradigm than the forms which fill them". Accordingly, in spite of their absence in the Duden dictionary, which actually witnesses of the lack of institutionalization (cf. Hohenhaus 2005), it is crucial in Table 1 that some of those potential words are attested as nonce-formations in large corpora and more in general on the Web. This makes them a concrete example of what availability actually means in this realm. For example, a word like kältestens 'most coldly', is attested in the following example taken from corpus $\mathrm{DeWaC}$ to which we refer henceforth for the actual web references:

Unser Versuch, in ein vollkommen untouristisches Bad zu gehen, war nicht wirklich erfolgreich: vom Besuch des Hamam direkt nördlich der GalataBrücke [...] sei wärmstens (bzw. kältestens) abgeraten.

'Our attempt to go in a completely un-touristic bathing facility wasn't really successful: be most warmly (or coldly) advised against visiting the hammam north from the Galata bridge.'

The nonce-formation kältestens appears to be licensed by the presence of the form, by contrast institutionalized and semantically specialized, wärmstens 'most warmly'. Further examples of kältestens found through a Google search occur in constructions which once again would usually contain wärmstens: ${ }^{4}$

\footnotetext{
${ }^{3}$ The symbol ${ }^{\circ}$ marks the output of the processes which are not attested in the Duden online dictionary available at www.duden.de.

${ }^{4}$ It is worth noting that Motsch (2004:282) in his treatment of the -ens de-adjectival adverbs of German explicitly excludes the existence of kältestens, as opposed to heißestens, and in general the possibility to produce the relevant antonym of an -ens adverb formed from an adjective constituting the higher pole of an antonymic scale.
} 
Diese drei Rezepte von klassischen Minze-Eistee bis zum fruchtigen ErdbeerEistee können wir kältestens empfehlen.

'We can most coldly recommend these three recipes from the classic Mint Ice Tea to the fruity Strawberry Ice Tea.'

In these two examples, it appears clearly how, for the sake of expressivity, constitutive elements of a lexicalized construction are replaced by alternative, previously unattested (or at least not institutionalized) elements whose existence is licensed by the specific context and by the meaning that the replaced element acquires in that specific context. We can define the adverb kältestens as a paradigmatic alternative to the institutionalized wärmstens, where 'paradigmatic' has the different sense, rooted in Saussure's associative relations, of 'being able to occur in the same syntagmatic slot'. Furthermore, potentiality makes reference to the paradigmatic strength of the associative relations insofar as the capacity of occurring in certain patterns is strengthened by the number of times this possibility is concretely exploited (counted both in types and tokens). In this light, the difference between the concept of paradigm "narrow sense" and "broad sense" hinted at above turns out to be rather of a quantitative nature (see Bauer's quote above on the "irregular" ways in which a slot in the paradigm can be filled) and refers to the degree of probability of actualization to the extent that "narrow sense" means more probably actualized and "broad sense" less probably actualized.

\section{The role of paradigms in compounding}

Turning our attention to compounding and taking again German hoch as example, it becomes clear that despite the intuitive appeal of Saussurean associative relations the concept of paradigm in this realm is more difficult to apply, at least in its entire implications. One has first to consider that the rich inventory of compounding patterns of German makes it possible for adjectives to be either heads or modifiers in compounds. An adjective like hoch can be connected to nouns to form new adjectives with the meaning of 'high as a N'.

$$
\begin{aligned}
& \text { a. Turm 'tower' + hoch 'high' > turmhoch 'high as a tower' } \\
& \text { b. Finger 'finger' + hoch 'high' > fingerhoch 'high as a finger' } \\
& \text { c. Mann 'man' + hoch 'high' > mannshoch 'high as a man' } \\
& \text { d. Wolkenkratzer 'sky-scraper' + hoch 'high' > wolkenkratzerhoch 'high } \\
& \text { as a sky-scraper' }
\end{aligned}
$$

The range of nouns modifying hoch in a compound is wide and encompasses nouns designating high objects (7a): Turm 'tower', as well as small ones (7b): Finger 'finger', possibly displaying linking elements as in mann-s-hoch $(7 \mathrm{c})$, and even nominal compounds $(7 \mathrm{~d}):\left[\left[[\text { Wolken }]_{\mathrm{N}}\left[[\text { kratz }]_{\mathrm{V}}-e r\right]_{\mathrm{N}}\right]_{\mathrm{N}} \text { hoch }\right]_{\mathrm{A}}$.

How can we apply in this case the concept of paradigm in the sense of a derivational family as suggested by Štekauer above? If we directly apply to hoch the logic of derivational processes as exemplified in (1c) above, the various nominal modifiers might be considered as processes which are applied to the adjective forming its 
derivational family; however, this does not make much sense, since it would imply that tens of nouns represent some kind of process as well. Conversely, if we consider hoch as a process - for example because all output formations are adjectivesfollowing the vertical axis of the paradigmatic relations suggested in (1b) above, we overlook the fact that these nouns can occur also in compounds with other adjectives as head, e.g. Turm can occur also in turmähnlich 'similar to a tower', turmbewehrt 'fortified with towers', turmbestückt 'provided with towers', turmgeschmückt 'decorated with towers' etc. Apparently, the paradigm in its narrow sense of a closed set of more or less structured and realized forms seems to be in most cases not useful in compounding, given the scarce advantage of conceiving words, even the head of a compound, as processes or constructions. On the other hand, the paradigm in its broad sense of a network of relations moving up and down within the Constructicon might be relevant in compounding but it does not seem to constrain the inventory of possible combinations to a closed set or at least to a limited set of alternatives.

However, this does not force us to conclude that the concept of derivational paradigm is of no help to model compounding. In fact, the concept of paradigm taken in its cross-referencing sense and modeled in a lexical network like the one seen in Fig. 1 above can be applied also to compounding, but only to a limited range of phenomena. If we turn our attention to the behavior of hoch as a modifier, it is possible to observe the relevance of the paradigm in a narrower sense. In the examples in (8ab) hoch modifies the adjectival heads, but it displays-rather than its usual meaning 'high' available for example in the compounds cited in (8c) — a specialized meaning 'very, highly':

(8) a. hochinteressant 'highly interesting', hochkomplex 'highly complex', hochaktuell 'very actual'

b. hochqualifiziert 'highly qualified', hochentwickelt 'highly developed', hochgeschätzt 'higly esteemed', hochgiftig 'highly poisonous'

c. hochgelegen 'lying in relatively big height', hochdosiert 'showing a high dosage', hochwertig 'having a high value', hochrangig 'high-ranked'

Accordingly, it has been suggested to consider this use of hoch as 'grammaticalized' insofar as it has undergone a process of semantic bleaching and expansion. Therefore, it constitutes one of the possibilities to express the elative in German, the other being the superlative (interessantest, but am interessantesten in most uses) and the use of grade adverbs (extrem interessant). As one of the strategies to express the elative, hoch- constitutes a paradigm on the horizontal axis seen in (1a) above insofar as it belongs together with the other strategies cited above to the same cognitive category of IELATIVEI. Interestingly, among the other strategies for expressing the elative, hoch- is the only one belonging to word-formation-though not to derivation stricto sensu - while the superlative, which can also be used as elative, is normally held to belong to inflection (but cf. Fuhrhop and Vogel 2010 for a discussion), while grade adverbs are modifiers at the syntactic level. This shows how paradigmatic relations involving a single cognitive category can in principle be established across several domains: inflection, word-formation, syntax. On the vertical axis (s. e.g. (1b-c) above), hoch- expressing IELATIVEl constitutes one of the forms available to an adjective (e.g. interessant) in the paradigm "narrow sense": hochinteressant is namely one of the 
possible formations that can be formed starting from the adjective beside the abstract noun Interessantheit 'interestingness', the adverb interessanterweise 'interestingly' etc.

We will again take into consideration the horizontal and the vertical axis of the paradigm relations in the realm of compounding in the next section where we will deal with a class of German synthetic compounds.

\section{Paradigmatic processes in compounding}

In this section, we move a step further towards morphological complexity discussing formations like the already cited hochwertig 'having a high value' and hochrangig 'high-ranked', in which -ig is an adjective-forming suffix and AN a possible compound (henceforth AN-ig formations). This rather complex pattern involves two lexical elements - an adjective and a noun — and the derivational suffix - $i g$ which is the most used suffix to form adjectives in German and is highly polysemous (DWB 3 1978:108-109). Up to 24 different uses for it can be listed, but, in the light of the high range of lexical categories that can access the process, we can consider -ig more generally as a category-shifting suffix, whose meaning contribution to the output changes in accordance with the input category. Among its uses a possessive meaning (dornige Hecke 'thorny hedges' = Hecke, die voller Dornen sind 'hedges which are full of thorns') is particularly frequent as far as nouns are concerned.

In the German-speaking literature, AN-ig formations are referred to as Zusammenbildungen ('combined formations', cf. Sugarewa 1972), a term indicating complex constructions in which a compound is connected to a suffix, but without the possibility to recognize a clear priority of the two processes as neither of the possible intermediate steps is actually attested:

$$
\begin{array}{ll}
\text { a. } & {\left[[\text { breit }]_{\mathrm{A}}[\text { kremp }]_{\mathrm{N}}-i g\right]_{\mathrm{A}} \text { 'wide-brimmed, having a wide brim' }} \\
\text { b. }{ }^{\circ}\left[[\text { Breit }]_{\mathrm{A}}[\text { krempe }]_{\mathrm{N}}\right]_{\mathrm{N}} \\
\text { c. }{ }^{\circ}\left[[\text { kremp }]_{\mathrm{N}}-i g\right]_{\mathrm{A}}
\end{array}
$$

The example in (9a) shows an AN-ig formation, breitkrempig 'wide-brimmed': neither of the possible formations which could constitute previous steps in generating it - the compound ${ }^{\circ}$ Breitkrempe 'wide-brim' or the derivative ${ }^{\circ}$ krempig 'brimmed' occurs, although both of them might be considered as possible but unattested words (see the discussion in Sect. 2 above). This state of affair is shared by many instances of synthetic compounds like English broad-shouldered or Dutch blauwogig 'blueeyed'. In the case of Dutch formations of this type Booij (?Boo2004:129, 2010:46) suggests that the two constructions available in Dutch word-formation, namely the not very productive construction producing AN compounds and the highly productive denominal derivation formed with the -ig suffix, are conflated giving rise to the unified constructional schema in (10a):

(10) a. $\left[\left[\mathrm{X}_{\mathrm{i}}\right]_{\mathrm{A}}\left[\left[\mathrm{Y}_{\mathrm{j}}\right]_{\mathrm{N}}-i g\right]_{\mathrm{A}}\right]_{\mathrm{A}} \leftrightarrow$ |having $\mathrm{SEM}_{\mathrm{j}}$ with a $\mathrm{SEM}_{\mathrm{i}} \mid$

b. $\left[\left[\left[\mathrm{X}_{\mathrm{i}}\right]_{\mathrm{A}}\left[\mathrm{Y}_{\mathrm{j}}\right]_{\mathrm{N}}\right]_{\mathrm{N}}-i g\right]_{\mathrm{A}} \leftrightarrow$ Iprovided with a $\mathrm{SEM}_{\mathrm{i}} \mathrm{SEM}_{\mathrm{j}} \mid$

c. $\left[\left[\mathrm{X}_{\mathrm{i}}\right]_{\mathrm{A}}\left[\mathrm{Y}_{\mathrm{j}}\right]_{\mathrm{N}}-i g\right]_{\mathrm{A}} \leftrightarrow$ |provided with a $\mathrm{SEM}_{\mathrm{i}} \mathrm{SEM}_{\mathrm{j}} \mid$ 
Table 2 Vertical and horizontal AN-ig formations clustering around hochherzig

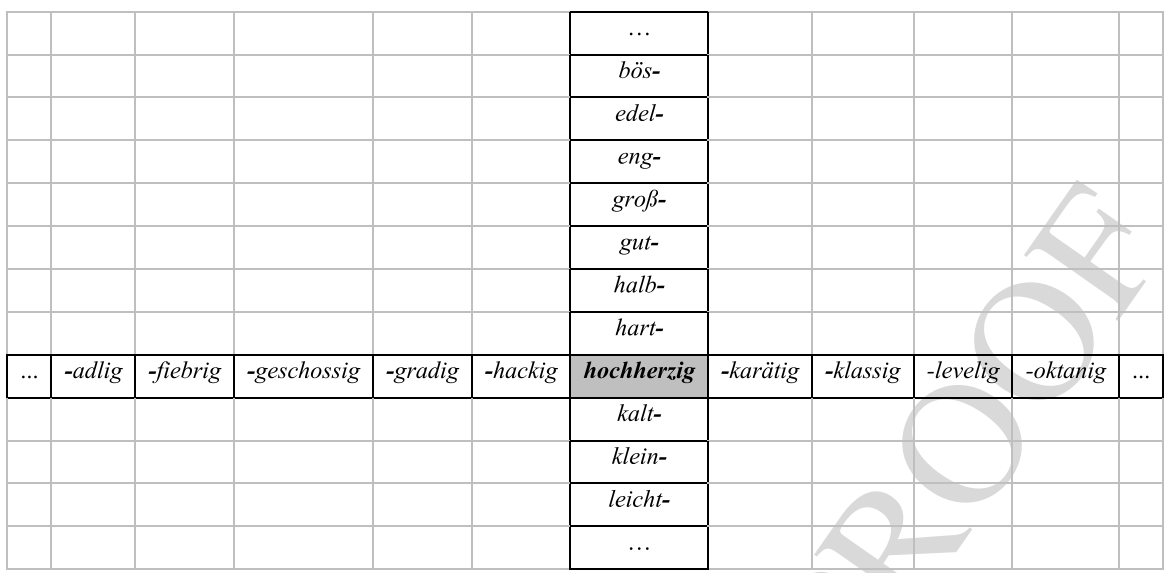

However, besides the conflated schema assumed by Booij, the representation in (10b) is also of relevance because it accounts for the case in which an AN compound does normally occur as in Graukopf 'gray-haired person' $\rightarrow$ grauköpfig 'gray-haired'. Since-as we hope to show below_-both (sub-)schemas are available, we prefer in what follows to adopt the flat representation in (10c) which strictly corresponds to the synthetic nature of these formations as they result from the simultaneous combination of the three morphemes involved. In fact, this constructional schema, which can straightforwardly be extended to German, is characterized by two open slots, one for adjectives and one for nouns, which can be simultaneously filled producing rich series of formations.

Elaborating further on this schema, the two slots can be conceived of as they can be filled freely by any adjective or noun. In the horizontal axis of Table 2 we list some formations featuring hoch as first constituent. The examples are taken from the 2-billion-token corpus DeWaC:

The nouns involved in the formations occurring along the horizontal axis of Table 2 have very different semantic features and hoch displays correspondingly different meaning nuances. We have abstract, uncountable nouns (Adel 'nobility', Fieber 'fever'), abstract, countable nouns (Grad 'degree', Karat 'carat', Klasse 'class', Level 'level', Oktan 'octane') and concrete, countable nouns (Geschoss 'floor', Hacke 'heel', Herz 'heart'). If we select one of these nouns, for example Herz 'heart', and look at the AN-ig formations in which it occurs along the vertical axis, we can observe a similar, long list of formations, one of which (hochherzig 'generous-hearted') is shared across this list and the former. In these formations, Herz 'heart' is never used in its proper, anatomic sense, but displays a metaphoric meaning as is revealed by the selection of adjectives indicating either properties referring to concrete objects (eng 'narrow', groß 'big', halb 'half', hart 'hard', hoch 'high', kalt 'cold', klein 'small', leicht 'light') or moral properties (böse 'evil', edel 'noble', gut 'good') both of which can be easily combined with the figurative meaning of Herz.-The examples in Table 2 show that the A and $\mathrm{N}$ slots in (10c) can be filled with many lexical 
Fig. 2 A constructional schema for the $\mathrm{AN}$-ig formations

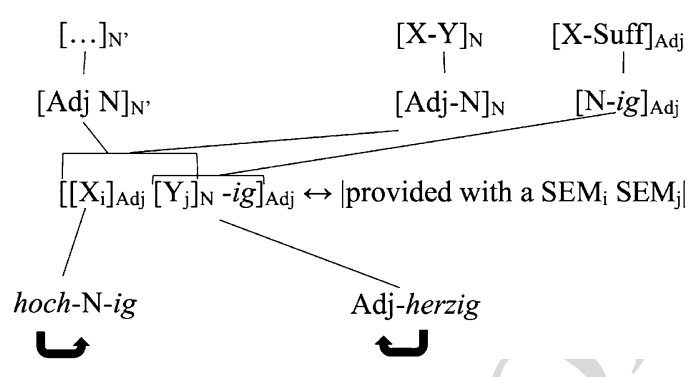

items, but they also exemplify the mutual selection preferences which characterizes the constituents of AN-ig formations. If an adjective like hoch is selected first, it narrows the possible filling of the $\mathrm{N}$ slot down to a range of nouns limited to those which are countable or, if not, to those which can be used with scalar sets of adjectives, as seen above. Conversely, if a noun like Herz is picked out first, it selects within the domain of adjectives like böse 'evil', edel 'noble', or gut 'good', etc. The mutual selection preferences observed uncover the presence of some kind of relation between the pairs of adjectives occurring in AN-ig formations. The schema in Fig. 2 is meant to express concretely the selection preferences emerging from the crisscrossing of paradigmatic and syntagmatic factors adopting the constructional approach seen in Sect. 2 above.

Note that in dependence of the access point selected, the two partially specified subschemas can be activated providing open variables respectively for nouns or adjectives. In Fig. 2 a peculiar role is played by the syntactic schema on the left side-in our examples this is implemented by the occurring noun phrases $\left[\left[[\text { hoh }-]_{\mathrm{Adj}^{\circ}}-e s\right]_{\mathrm{Adj}},[\text { Herz }]_{\mathrm{N}^{\circ}}\right]_{\mathrm{N}}$, and $\left[\left[[\text { breit- }]_{\mathrm{Adj}^{\circ}}-e\right]_{\mathrm{Adj}},[\text { Krempe }]_{\mathrm{N}^{\circ}}\right]_{\mathrm{N}}$, - which is directly wired with the partially specified morphological schema accounting for the $\mathrm{AN}-i g$ formations and actually motivates hochherzig and breitkrempig. This relation is clearly syntagmatic as it refers to the co-occurrence of these nouns and adjectives in syntax. We will return to these syntagmatic relations in Sect. 7 below.

\section{From syntagmatic relations to paradigmatic alternations}

The possibility for adjectives and nouns to restrict their selection possibilities of, respectively, nouns and adjectives entering the AN-ig formations is a process that transfers syntagmatic preferences on the level of paradigmatic alternations. As seen above, both the nouns occurring in compounds featuring adjective hoch and the adjectives occurring in compounds featuring noun Herz can be grouped in sets of elements sharing some semantic property. Widening the scope beyond the examples of Table 2, with the help of data extracted from the sub-corpus DeWac-1 (about 90 million tokens) we can observe numerous series of $\mathrm{AN}-i g$ formations with common adjectives or common nouns which constitute partially instantiated constructional schemas. As far as adjectives are concerned, many of them can be further grouped together in antonymic pairs (11a) or in scalar sets $(11 b-c)$. 

a. hoch- 'high' $\sim$ niedrig-/nieder- 'low'; breit- 'wide' eng- 'narrow'; warm- 'warm' kalt- 'cold'
b. lang-, mittel-, kurz-, längerfristig 'of long, middle, short or longer term'
c. groß-, mittel-, kleinkronig '(of trees) with a huge, middle or small crown of foliage'

We will discuss later in Sect. 7 the relations among groups of constructional schemas with a filled A slot. Turning the attention to nouns, concrete nouns-sometimes used in a metaphoric sense, see the example of Herz in Table 2 above-are common. The adjectives used in these formations describe properties displayed by the actual referent rather than indicating a specific class of these objects, as in the following examples based on different concrete nouns:
a. Knochen 'bone': dürr-, stark-, schwerknochig 'of thin, strong, heavy bones'
b. Korn 'grain': fein-, grobkörnig 'fine-, rough-grained'

Measure nouns, which are characterized by being abstract and countable, are compatible with a wider range of adjectives. It is worth noting that the use of the comparative and of the superlative form of the adjective is possible and allows finer nuances as in (13a):

Grad 'grade, degree':

a. hoch-, höher-, höchst-, mittel-, niedriggradig 'of high/higher/highest, middle, low degree'

b. erst-, drittgradig 'of first, third degree'

c. verschiedengradig 'of different degrees'

Countable properties of some nouns occurring in the AN-ig formations are evident in the examples in (13b-c) and are further exploited in the constructional schema in (14), which is very productive in German and can be conceived as a subschema of (10) above: e.g., zehngradiges Bier 'beer having 10\% alcohol content':

(14) $\left[\left[\mathrm{X}_{\mathrm{i}}\right]_{\mathrm{Num}}\left[\mathrm{Y}_{\mathrm{j}}\right]_{\mathrm{N}}-i g\right]_{\mathrm{A}} \leftrightarrow$ |provided with an amount of $\mathrm{SEM}_{\mathrm{i}} \mathrm{SEM}_{\mathrm{j}} \mathrm{I}$

Countable nouns can occur in both schemas, which are thus intersected, as far as noun constituents are concerned. Abstract nouns that fill the $\mathrm{N}$ slot of AN-ig formations can build long series of formations. For example, inserting the noun Farbe 'color' in the schema in (10) one can build mostly color adjectives like those in (15a):

(15) a. beige-, grau-, orange-, sepiafarbig 'beige-/grey-/orange-/sepia-colored'

b. hell-, dunkelfarbig 'light-/dark-colored'

c. gleich-, anders-, vielfarbig 'of the same/another/many colors'

While in most cases $\left[\mathrm{X}_{\mathrm{i}}\right]_{\mathrm{A}}$ is a color adjective as in (15a), the slot can be filled also by adjectives indicating degrees of brightness (15b) or even similarity and variety (15c).

The high productivity of the partially instantiated subschema $\left[\left[\mathrm{X}_{\mathrm{i}}\right]_{\mathrm{A}}[\text { farb- }]_{\mathrm{N}}-i g\right]_{\mathrm{A}}$ $\leftrightarrow$ 'having SEM $_{\mathrm{i}}$ color', accompanied by the occurrence of the adjective farbig, which facilitates the segmentation of the $\mathrm{AN}-i g$ formations but at the same time conveys the partially different meaning 'colorful, full of colors' (see fn. 4 for the similar 
Stripping paradigmatic relations out of the syntax

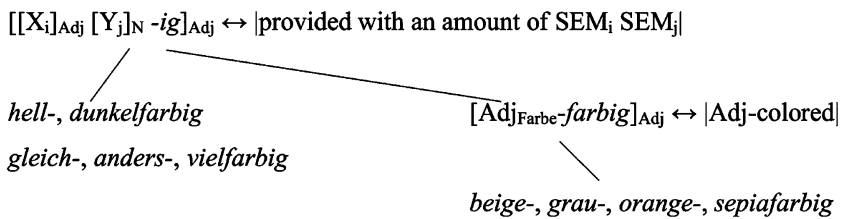

Fig. 3 A constructional schema for the semi-suffix -farbig

case of stämmig), favors its reanalysis in terms of a suffix-like unit resulting from a process of grammaticalization. In fact, in the German-speaking literature, -farbig has been treated as a suffixoid (cf. DWB 3:427, 499), or as a semi-affix (cf. Marchand 1969:356, Vögeding 1981, cf. the discussion in Fleischer and Barz 1992:27, 236, Decroos and Leuschner 2008; Van Goethem 2008), stressing in particular the patternrestricted meaning displayed in the instantiated subschema as a whole. As will be argued in Sect. 7 below, the main semantic effect connected with the semi-affix consists in reducing the modifying nature of these determinative compounds, because the first elements do not serve to sub-classify their respective heads as in normal compounding; rather, the semi-affixes elaborate communicatively relevant categories in paradigmatic terms enhancing the role of the first adjective with respect to the head (cf. Eichinger 2000:98). In other terms, the relevant information provided by the formation orangefarbig in the NP ein orangefarbiges Hemd 'an orange-colored shirt' is the strict relation expressed between orange and Hemd rather than the subclassification of farbig by means of orange, which makes it similar to a true adjectival suffix such as -ern in the NP ein hölzerner Nachttisch 'a wooden nightstand'.

The constructional schema in Fig. 3 results from the partial elaboration of the general schema in Fig. 2 accommodating on its right side the semi-suffix -farbig as it systematically selects color adjectives.

It has to be added that this is not the only candidate for such a treatment that can be found in the data, and we can speak in fact of a general process of semi-suffixation involving a number of possible candidates. It is important to stress the developmental perspective adopted in the discussion of these phenomena of semi-suffixation because the latter can only be properly accommodated in the general frame of an emergent grammar, as it is commonly understood in the construction-grammatical approach as well as in grammaticalization studies, cf. respectively Bybee (2013) and Hopper and Traugott (2003:35).

If we look at the N slot of AN-ig formations, nouns like Sprache 'language' and Stamm 'root' also contribute to build complex adjectives indicating language and national or ethnic groups, as shown by the examples respectively in (16a-b):

(16) a. albanisch-sprachig/-stämmig, deutsch-sprachig/-stämmig 'of Albanian, German language/roots'

b. jiddischsprachig 'of Yiddisch language' jüdischstämmig 'of Jewish roots'

c. gleich-/verschiedensprachig 'of the same/a different language'

Compounds displaying the nouns Sprache or Stamm are numerous: we count more than 80 adjectives indicating ethnonyms connected with one or both of them. It is 


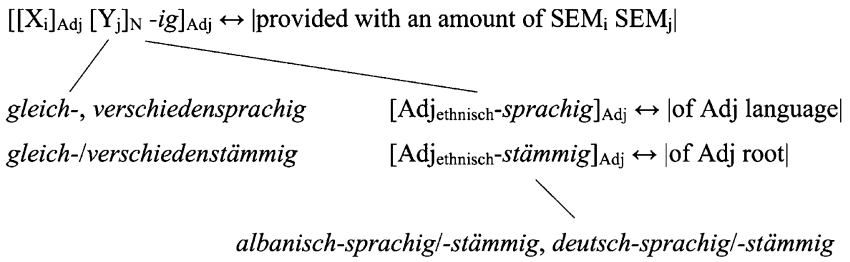

Fig. 4 A constructional schema for the semi-suffixes -sprachig and-stämmig

$<\begin{gathered}\text { horizontal axis } \\ \text { Albanisch 'Albanian (A)', } \\ \text { Albaner }\end{gathered}$

Fig. 5 Horizontal and vertical axes in compounding

worth noting that -sprachig and -stämmig occur with the same ethnonyms, while cases like (16b), in which an adjective specifically indicates a language and another one indicates the ethnic group membership, are rather an exception. As in the case of -farbig also more general adjectives are compatible with the subschema, as shown by the examples in (16c). Figure 4 expresses in the usual constructional terms the status of semi-suffixes of -sprachig and -stämmig resulting as a partial elaboration of the general schemas shown in Fig. 2 above.

The rise of partially instantiated schemas like -farbig, -sprachig and -stämmig makes both the vertical and the horizontal axis of paradigmatic relations accessible to these subschemas which, as said, are often conceived as almost derivational processes: they can in principle alternate or compete with other derivational strategies.

For example, -sprachig and -stämmig, which are applied to adjectives indicating ethnic/national membership, can belong to both the vertical and horizontal axis of a paradigm in which other processes related to ethnic or national membership occur, for example processes forming nouns of inhabitants, as visualized in Fig. 5.

This example shows once again that also products of compounding can be included in a derivational paradigm. Obviously, compounding processes tend to display a richer intensionality, which correspondingly allows one to carve out a narrower and precise meaning, as we can see in the examples in Fig. 5: (ein) Albanischstämmiger refers to a 'male of Albanian ethnicity' while its competitor Albaner, which is derived from Albanien 'Albania' through derivation via the -er suffix, has a broader meaning, which includes a more general sense 'inhabitant of Albania'.

While-in the perspective opened by grammaticalization-compounding is generally a source of new suffixes resulting from grammaticalization processes (as shown for example by cases like -heit, -lich and -los, which occur respectively in Schönheit 
'beauty', freundlich 'friendly' and bedeutungslos 'meaningless' and go back to the older lexemes heit 'figure', līch 'body' and $l \bar{s} s$ 'loose'), it can also participate to some extent to existing derivational paradigms. In the next section, we will evaluate how paradigms specific to compounding can rise and how they are enriched and structured.

\section{Paradigm families in compounding}

Even if -farbig, -sprachig and -stämmig can be conceived as semi-suffixes, in the relevant compounds the semantic scope of the adjective in the A slot is always on the noun and does not expand over the full -N-ig part of the schema. Thus, orangefarbig 'having an orange color', albanisch-stämmig 'of Albanian roots' do not mean, respectively, 'orange-colorful' and 'Albanian-vigorous'.

The meaning of the adjectives occurring in AN-ig formations corresponds to the meaning of the corresponding adjective noun sequences:

\section{feinkörnig 'fine-grained' $\approx$ feines Korn 'fine grain'}

In this example, fein qualifies grains (Korn) as 'fine' as in the corresponding AN phrase. More in general, the adjectives in AN-ig formations display a non-classifying, qualifying function (cf. Schlücker 2013), which essentially differs from the more usual classifying function generally displayed by modifiers in compounds, including AN compounds:

\section{a. Süßkartoffel 'sweet potato (type of vegetable, Ipomoea batatas)'}

b. süße Kartoffel 'sweet potato (a potato which tastes sweet)'

In (18a) sü $\beta$ has a classifying function insofar as it serves as a label for identifying a specific kind of vegetable (properly not a kind of potato). Even if the adjective 'sweet' is used because this kind of vegetables is in general sweet, it does not mean that a specific item of this species is necessarily sweet: Süßkartoffel may have a bitter taste, which does not imply renaming that item as *Bitterkartoffel. The qualifying function of adjectives in $\mathrm{AN}-\mathrm{ig}$ formations complies with the usual function of adjectives in syntax and suggests the need of checking to what extent the syntagmatic relation already evoked above between specific adjectives and nouns plays a role in motivating the formations attested in the corpus.

In some cases, the frequency of $\mathrm{AN}-i g$ formations mirrors that of the corresponding AN phrases. In Table 3 the parallel decrease in frequency of A-sprachig compounds and their [A Sprache $]_{N P}$ correspondents taken from a 90-million-token subcorpus of DeWaC is reported:

More importantly, of 62 pairs of ethnic adjective and -sprachig attested in AN-ig formations in the subcorpus, 60 are attested as $\mathrm{AN}$ phrases in the whole DeWaC.

It must be added that not always the AN-ig formations directly mirror the syntactic use of their corresponding AN phrases. We have already encountered the compounds hoch- and niedriggradig 'of high/low degree'. They correspond to phrases

\footnotetext{
${ }^{5}$ The derivative stämmig, from Stamm 'root', exists, but means in fact 'strong, vigorous, athletic'.
} 
Table 3 AN-ig formations and their corresponding AN phrases

\begin{tabular}{llll}
\hline AN-ig formation & Frequency & Corresponding AN phrase & Frequency \\
\hline deutschsprachig & 1697 & deutsche Sprache & 1214 \\
französischsprachig & 62 & französische Sprache & 137 \\
türkischsprachig & 29 & türkische Sprache & 48 \\
jiddischsprachig & 1 & jiddische Sprache & 8 \\
\hline
\end{tabular}

like hoher Grad, niedriger Grad. It is worth noting that the NP built on the lemmas hoch and Grad in the whole DeWaC corpus is almost a hundred times more frequent than the NP built on niedrig and Grad (2124 vs. 26 occurrences) and this is reflected by the even higher difference of the token frequency of the corresponding compounds (hochgradig:5515; niedriggradig:19). In other words, the frequently attested NP formed with hoch and Grad licenses the compound hochgradig, and it is the associative relation of the antonyms hoch and niedrig that makes the formation of niedriggradig available rather than the NP formed with niedrig and Grad which displays a low token frequency. An associative relation in syntax is thus transferred to a compound creating an associative relation-a small paradigm-in compounding. This small paradigm is based on the alternation of the two adjectives hoch and niedrig which fill the A slot of the general AN-ig constructional schema and can be further expanded, as we will see below.

Furthermore, relations established on the syntagmatic level do not only affect the A slot, but also the $\mathrm{N}$ slot. Let's take for instance the pair of formations hochand niedrigohmig 'of high/low Ohm-value'. In contrast with the case of hoch-and niedriggradig, the phrases hohes $\mathrm{Ohm}$ and niedriges $\mathrm{Ohm}$ are not attested at all. However, in its syntactic use we can find the noun $\mathrm{Ohm}$ - which is the measure unit of electrical resistance $(\Omega)$ - preceded by a numeral:

\section{die aktiven [Terminatoren] werden mit einer Spannung von 2,85 V versorgt und besitzen einen Widerstand von $110 \mathrm{Ohm}$ \\ 'the active terminators are supplied with a voltage of $2.85 \mathrm{~V}$ and display a resistance of $110 \Omega$ '}

Since they express a measure unit and strongly depend on the context, different numerical quantities correspond to what is a high or low Ohm-value. Therefore, similar to a zehngradiges Bier which is also a hochgradiges Bier, a value of electrical resistance can be hoch or nieder-/niedrigohmig ${ }^{6}$ :

(20) Die Entgegenhaltung nutzt damit für ihre Füllstandsüberwachung nicht nur den niederohmigen Widerstandsbereich einerseits und den hochohmigen Widerstandsbereich andererseits

'Thus, the anticipation not only exploits for the monitoring of the filling level the low ohm resistance range on the one hand and the high ohm resistance range on the other'

\footnotetext{
${ }^{6}$ The adjective niedrig is properly a derivative of the adverb nieder 'low' and the latter often occurs in alternation with the former in AN-ig formations.
} 
It is thus possible to identify a paradigm of partially instantiated constructional schemas, like that in (21), in which the free slot can be filled by nouns characterized by the property of being countable measure units:

$\left[\text { hoch- }\left[\mathrm{X}_{\mathrm{i}}\right]_{\mathrm{N}}-i g\right]_{\mathrm{A}} \leftrightarrow \mid$ provided with a high $\mathrm{SEM}_{\mathrm{i}} \mid \sim$ niedrig- $\left.\left[\mathrm{X}_{\mathrm{i}}\right]_{\mathrm{N}}-i g\right]_{\mathrm{A}} \leftrightarrow$ |provided with a low $\mathrm{SEM}_{\mathrm{i}} \mid$

Consequently, beyond the relation between AN-ig formations and the corresponding AN phrases, a partially instantiated constructional schema can be enriched with paradigmatic alternatives independently of the occurrence of AN phrases motivating them in syntax.

Turning again our attention to the A slot, we can see that also in this case paradigmatic alternatives can be expanded without recurring to relations established at the syntactic level.

The paradigm in (21) is not unique and a number of other pairs of antonyms can occur in the A slot. In (22a) and (22b) two further paradigm families are listed and some examples are provided respectively in (22c) and (22d):

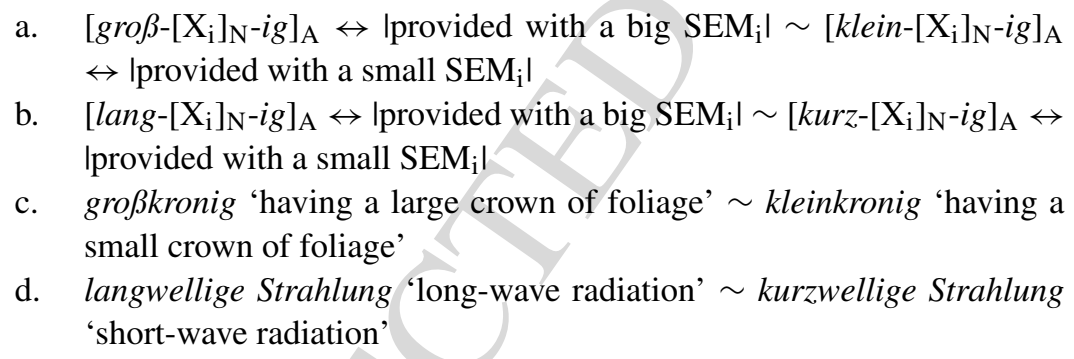

In the specific case of the examples in (22d), they can actually be derived by two existing AN compounds, Langwelle and Kurzwelle which indicate radiations belonging to two different ranges of frequencies - respectively 30 to $300 \mathrm{KHz}$ and 3 to $30 \mathrm{MHz}$. A third range of frequencies - from $300 \mathrm{KHz}$ to $3000 \mathrm{KHz}$ (i.e. $3 \mathrm{MHz}$ ) — corresponds to the term Mittelwelle, a compound ${ }^{7}$ which in fact shows the highly productive use of Mittel- as first constituent in nominal compounds, as shown by the schema in (23a) and the relevant examples in (23b) below:

a. $\quad\left[\text { Mittel- }\left[\mathrm{X}_{\mathrm{i}}\right]_{\mathrm{N}}\right]_{\mathrm{N}} \leftrightarrow \mid$ middle $\mathrm{SEM}_{\mathrm{i}} \mid$

b. Mittelalter 'the Middle Ages', Mittelpunkt 'central point', Mittelmeer 'Mediterranean', Mittelfeld 'middle field', Mittelklasse 'mid-range, middle class', Mittelstufe 'middle school', Mittelwelle 'medium frequency'

${ }^{7}$ At first sight, Mittel- in Mittelwelle might be connected either with the adjective mittel 'neither good or bad, average' or with the noun Mittel which can refer to 'means, resources, remedy' or to 'middle value', and in this latter meaning is related to the adjective (and historically derived from it). However, for the compounds in (23) the association with the adjective is preferable in the light of other compounds which clearly select the noun Mittel 'mean' such as Mittelbestand 'funds, lit. stock of resources', Mittelbedarf 'resource needs', etc. 
Table 4 Paradigm families on the basis of the AN-ig pattern

\begin{tabular}{|c|c|c|}
\hline $\begin{array}{l}{\left[\text { hoch }-\left[\mathrm{X}_{\mathrm{i}}\right]_{\mathrm{N}}-i g\right]_{\mathrm{A}} \leftrightarrow \mid \text { provided }} \\
\text { with a high } \mathrm{SEM}_{\mathrm{i}} \mid\end{array}$ & $\begin{array}{l}{\left[\operatorname{gro} \beta-\left[\mathrm{X}_{\mathrm{i}}\right]_{\mathrm{N}}-i g\right]_{\mathrm{A}} \leftrightarrow \mid \text { provided }} \\
\text { with a big } \mathrm{SEM}_{\mathrm{i}} \mid\end{array}$ & $\begin{array}{l}{\left[\text { lang- }\left[\mathrm{X}_{\mathrm{i}}\right]_{\mathrm{N}}-i g\right]_{\mathrm{A}} \leftrightarrow \text { |provided }} \\
\text { with a long } \mathrm{SEM}_{\mathrm{i}} \mid\end{array}$ \\
\hline \multicolumn{3}{|c|}{$\left[\text { mittel }-\left[\mathrm{X}_{\mathrm{i}}\right]_{\mathrm{N}}-i g\right]_{\mathrm{A}} \leftrightarrow \mid$ provided with an average amount of $\mathrm{SEM}_{\mathrm{i}} \mid$} \\
\hline $\begin{array}{l}{\left[\text { niedrig }-\left[\mathrm{X}_{\mathrm{i}}\right]_{\mathrm{N}}-i g\right]_{\mathrm{A}} \leftrightarrow \text { |provided }} \\
\text { with a low } \mathrm{SEM}_{\mathrm{i}} \mid\end{array}$ & $\begin{array}{l}{\left[\text { klein- }\left[\mathrm{X}_{\mathrm{i}}\right]_{\mathrm{N}}-i g\right]_{\mathrm{A}} \leftrightarrow \mid \text { provided }} \\
\text { with a small } \mathrm{SEM}_{\mathrm{i}} \mid\end{array}$ & $\begin{array}{l}{\left[k u r z-\left[\mathrm{X}_{\mathrm{i}}\right]_{\mathrm{N}}-i g\right]_{\mathrm{A}} \leftrightarrow \text { |provided }} \\
\text { with a short } \mathrm{SEM}_{\mathrm{i}} \mid\end{array}$ \\
\hline
\end{tabular}

Some of the examples in (23b) has a counterpart in an AN-ig formation as shown by the examples in (24a) below, but many other instantiations without a NN compound as counterpart are also attested as shown by (24b):

a. mittelaltrig 'related to the Middle Ages', ${ }^{8}$ mittelklassig 'of mid-range; related to middle class', mittelwellig 'related to medium frequencies'

b. mittelformatig 'of middle format', mittelgradig 'of middle degree/grade', mittelkettig 'of middle chain', mittelohmig 'of middle Ohm-value', mittelrangig 'of middle rank', mitteltönig 'of mean tone'

The latter constitute instantiations of another schema in which mittel- fills the first slot:

$$
\left[\text { mittel- }\left[\mathrm{X}_{\mathrm{i}}\right]_{\mathrm{N}}-i g\right]_{\mathrm{A}} \leftrightarrow \text { |provided with an average amount of } \mathrm{SEM}_{\mathrm{i}} \mid
$$

This schema, which lacks any relation with the syntactic level, has rather arisen in the realm of compounding (see also the conflation schema in (10a) above). It perfectly fits in the paradigms in (21) and (22a-b) above and constitutes a third process available for building $\mathrm{AN}-\mathrm{ig}$ formations as summarized by Table 4.

\section{Conclusion}

To sum up, in this contribution we hope to have shown how paradigmatic word formation looks like with special attention paid to compounding. Štekauer's idea of a horizontal and a vertical axis proved very useful for identifying concrete paradigmatic or associative relations with the help of large text corpora. In this regard, exploiting schemas connected by means of inheritance relations which give rise to partially filled subschemas as is commonly assumed in Booij's Construction Morphology has helped us to represent paradigm families reflecting direct connections between what results from word formation proper and what is the instantiation of syntactic constructions. Accordingly, we have shown how syntagmatic and paradigmatic relations developed in syntax find their way into word formation which inherits and further expands such relations in an autonomous way. Furthermore, the most productive schemas may end up in constituting semi-affixations which are in turn a first step toward derivation proper. In particular, we have been able to identify on the one hand different processes of semi-suffixation involving subdomains of the lexicon curtailing well-defined input bases (color and ethnic adjectives), and on the other a whole

\footnotetext{
${ }^{8}$ More commonly the adjective derived for Mittelalter 'the Middle Ages' is mittelalterlich.
} 
paradigmatic set of relations giving rise to contrasts like mittelwellig vs. mittelgradig where the latter displays purely paradigmatic meaning. In this sense, paradigmatic relations in word formation are the initial stage of a grammaticalization cline in which such relations are looser in compounding and become tighter in derivation. This processual conception fits in very well with an emergentist view of grammar couched within a usage-based approach as is commonly assumed in Construction Grammar.

\section{References}

Angster, M. (2009). Composizione e parasintesi negli aggettivi in tedesco: $i$ tipi rotwangig, salzhaltig, risikofreudig in un corpus Web. Unpublished MA thesis, University of Turin.

Aronoff, M. (1976). Word formation in generative grammar. Massachusetts: MIT Press.

Baerman, M., \& Corbett, G. G. (2010). Introduction: defectiveness: typology and diachrony. Proceedings of the British Academy, 163, 1-18.

Baroni, M., Bernardini, S., Ferraresi, A., \& Zanchetta, E. (2009). The WaCky wide web: a collection of very large linguistically processed web-crawled corpora. Language Resources and Evaluation, 43(3), 209-226.

Bauer, L. (1997). Derivational morphology. In G. Booij \& J. van Marle (Eds.), Yearbook of morphology 1996 (pp. 243-256). Dordrecht: Kluwer.

Bauer, L. (2001). Morphological productivity. Cambridge: Cambridge University Press.

Booij, G. (2010). Construction morphology. Oxford: Oxford University Press.

Bybee, J. L. (2013). Usage-based theory and exemplar representation. In T. Hoffman \& G. Trousdale (Eds.), The Oxford handbook of construction grammar (pp. 49-69). Oxford: Oxford University Press.

Carstairs, A. (1987). Allomorphy in inflexion. London: Croom Helm.

Decroos, N., \& Leuschner, T. (2008). Wortbildung zwischen System und Norm: Affixoide im Deutschen und im Niederländischen. Sprachwissenschaft, 33, 1-34.

DWB 3 = Kühnhold, I., Putzer, O., \& Wellmann, H. (1978). Deutsche Wortbildung: Typen und Tendenzen in der Gegenwartsprache, Hauptteil 3: Das Adjektiv. Düsseldorf: Schwann.

Eichinger, L. M. (2000). Deutsche Wortbildung: Eine Einführung. Tübingen: Gunter Narr.

Fleischer, W., \& Barz, I. (1992). Wortbildung der deutschen Gegenwartssprache. Tübingen: Niemeyer.

Fuhrhop, N., \& Vogel, P. (2010). Analytisches und Synthetisches im deutschen Superlativ. In D. Bittner \& L. Gaeta (Eds.), Kodierungstechniken im Wandel: Das Zusammenspiel von Analytik und Synthese im Gegenwartsdeutschen (pp. 83-97). Berlin: de Gruyter.

Furdík, J. (2004). Slovenská slovotvorba [Slovak word-formation]. Prešov: Náuka.

Gaeta, L. (2006). Lexical integrity as a constructional strategy. Lingue E Linguaggio, 5(1), 67-82.

Gaeta, L. (2007). On the double nature of productivity in inflectional morphology. Morphology, 17(2), 181-205.

Gaeta, L. (2010). Polysynthese, Multifunktionalität und die denominalen Adjektive im Deutschen. In D. Bittner \& L. Gaeta (Eds.), Kodierungstechniken im Wandel: Das Zusammenspiel von Analytik und Synthese im Gegenwartsdeutschen (pp. 99-121). Berlin: de Gruyter.

Gaeta, L. (2013). Affix ordering and conversion: looking for the place of zero. Lingue E Linguaggio, 12(2), $145-170$.

Gaeta, L. (2014). On decategorization and its relevance in German. In R. Simone \& F. Masini (Eds.), Word classes: nature, typology and representations (pp. 227-241). Amsterdam: Benjamins.

Gaeta, L. (2015). Restrictions in word formation. In P. O. Müller, I. Ohnheiser, S. Olsen, \& F. Rainer (Eds.), Word-formation: An international handbook of the languages of Europe (Vol. 2, pp. 858-874). Berlin: Mouton de Gruyter.

Gaeta, L., \& Ricca, D. (2015). Productivity. In P. O. Müller, I. Ohnheiser, S. Olsen, \& F. Rainer (Eds.), Word-formation: An international handbook of the languages of Europe (Vol. 2, pp. 841-858). Berlin: Mouton de Gruyter.

Gaeta, L., \& Zeldes, A. (2017). Between VP and NN: On the constructional types of German -er compounds. Constructions and Frames, 9(1), 1-40.

Goldberg, A. E. (2013). Constructionist approaches to language. In T. Hoffmann \& G. Trousdale (Eds.), The Oxford handbook of construction grammar (pp. 15-31). Oxford: Oxford University Press. 
«JOMO 11525 layout: Small Extended v.2.1 file: jomo9326.tex () class: spr-small-v1.4 v.2017/12/27 Prn:2018/05/24; 10:47 p. 22/22»

Hohenhaus, P. (2005). Lexicalization and institutionalization. In P. Štekauer \& R. Lieber (Eds.), Handbook of word-formation (pp. 353-373). Dordrecht: Springer.

Hopper, P. J., \& Traugott, E. C. (2003). Grammaticalization (2nd ed.). Cambridge: Cambridge University Press.

Jackendoff, R., \& Audring, J. (2016). Morphological schemas: theoretical and psycholinguistic issues. The Mental Lexicon, 11(3), 467-493.

Marchand, H. (1969). The categories and types of present-day English word-formation: A synchronicdiachronic approach (2nd ed.). München: Beck.

Motsch, W. (2004). Deutsche Wortbildung in Grundzügen (2nd ed.). Berlin: Mouton de Gruyter.

Scalise, S. (1984). Generative morphology. Dordrecht: Foris.

Schlücker, B. (2013). Non-classifying compounds in German. Folia Linguistica, 47(2), 449-480.

Štekauer, P. (2014). Derivational paradigms. In R. Lieber \& P. Štekauer (Eds.), The Oxford handbook of derivational morphology (pp. 354-369). Oxford: Oxford University Press.

Štekauer, P. (2015). The delimitation of derivation and inflection. In P. O. Müller, I. Ohnheiser, S. Olsen, \& F. Rainer (Eds.), Word-formation: An international handbook of the languages of Europe (Vol. 1, pp. 218-235). Berlin: Mouton De Gruyter.

Stump, G. T. (2005). Word-formation and inflectional morphology. In P. Štekauer \& R. Lieber (Eds.), Handbook of word-formation (pp. 49-71). Dordrecht: Springer.

Sugarewa, T. (1972). Zu den Wortbildungstypen 'breitkrempig', 'zielstrebig', 'langgeschwärt'. Beiträge zur Geschichte der deutschen Sprache und Literatur, 93, 259-298 (Halle, Saale).

Van Goethem, K. (2008). Oud-leerling versus ancien élève: A comparative study of adjectives grammaticalizing into prefixes in Dutch and French. Morphology, 18, 27-49.

1005

1006

Vögeding, J. (1981). Das Halbsuffix ,,-frei“: Zur Theorie der Wortbildung. Tübingen: Gunter Narr.

1007

1008

1009

1010

1011

1012

1013

1014

1015

1016

1017

1018

1019

1020

1021

1022

1023

1024

1025

1026

1027

1028

1029

1030

1031

1032

1033

1034 